3. Б.-Д. Дондоков, А. Б. Базаров. Ретроспективный анализ экономической эффективности маршрутов монгольского коридора

УДК 316.334

DOI 10.18101/2304-4446-2019-1-3-8

\title{
РЕТРОСПЕКТИВНЫЙ АНАЛИЗ ЭКОНОМИЧЕСКОЙ ЭФФЕКТИВНОСТИ МАРШРУТОВ МОНГОЛЬСКОГО КОРИДОРА
}

\section{(C) Дондоков Зорикто Бато-Дугарович}

доктор экономических наук, главный научный сотрудник,

Отдел региональных экономических исследований БНЦ СО РАН, Бурятский государственный университет, профессор

Россия, 670000, г. Улан-Удэ, ул. Сахьяновой, 8

E-mail: orei.bnc@mail.ru

\section{(C) Базаров Александр Борисович}

обучающийся, Бурятский государственный университет

Россия, 670000, г. Улан-Удэ, ул. Смолина, 24а

E-mail: sasha.bazarov.97@bk.ru

В статье проводится ретроспективный анализ экономической эффективности маршрутов монгольского коридора. Сформирован перечень важнейших условий и свойств груза для формирования экономического коридора и торговли между странами. Определены причины формирования устойчивого спроса на чай и рассмотрено его становление как основного предмета торговли между Китаем и Россией. Проанализированы основной Кяхтинский и альтернативные ему Амурский, Бийский, Туркестанский и морской чайные пути, приведены основные точки маршрута, их преимущества и недостатки. Приведены результаты расчетов затрат на чайных маршрутах. Определены причины снижения конкурентоспособности кяхтинского маршрута. Сформулированы рекомендации к современным условиям создаваемого экономического коридора «Китай - Монголия - Россия».

Ключевые слова: перевозка грузов; чайные маршруты; монгольский коридор; затраты на доставку чая.

\section{Для цитирования:}

Дондоков 3. Б.-Д., Базаров А. Б. Ретроспективный анализ экономической эффективности маршрутов монгольского коридора // Вестник Бурятского государственного университета. Экономика и менеджмент. 2019. Вып. 1. С. 3-8.

В условиях глобализации важной задачей становится изучение исторического опыта трансграничного взаимодействия, развития транспортных и торговых связей. В контексте создания экономического коридора «Китай - Монголия Россия» значительный интерес представляет исследование Великого чайного пути (ВЧП), бравшего свое начало в Китае, пересекавшего территорию Монголии и через Россию доходившего до Европы.

Важнейшим условием создания экономического коридора является эффективность перевозки груза. С древних времен торговля является наиболее простой и распространенной формой международного экономического взаимодействия. При движении на длительные расстояния и низкой скорости на дорогу мог уходить не один месяц. Поэтому сотни лет назад перевозимые далеко товары должны были обладать определенными свойствами. 
Во-первых, наличие у потенциальных покупателей устойчивого спроса на привозимую продукцию. Она должна обладать уникальными потребительскими свойствами и не производиться на данной территории.

Во-вторых, высокая устойчивость к порче. Немногие товары могли отвечать этим требованиям. Так, отсутствие возможности поддерживать определенный температурный режим накладывало жесткие ограничения на перевозку свежих продуктов питания.

В-третьих, для перевозки сухопутным путем непреодолимым барьером большинства товаров была низкая «мощность» тягловой силы (лошадей, мулов, верблюдов и т. п.). В силу этого перевозка объемных и малоценных грузов на длительные расстояния становилась экономически нецелесообразной. Таким образом, перевозимый товар должен быть компактным и достаточно ценным, чтобы затраты на его транспортировку были относительно невелики.

С давних времен предъявляемыми свойствами обладали лишь некоторые товары, например, шелк, специи, фарфор, драгоценные камни и металлы. К этой группе избранных относился и чай.

Во-первых, к началу XIX в. в России сформировался устойчивый спрос на чай не только со стороны элиты общества, но и массовых потребителей. Появились определенная культура чаепития, специальные заведения - чайные, а также соответствующее оборудование, включая самовары [4].

Во-вторых, чай достаточно хорошо сохраняется при соответствующей упаковке и соблюдении условий перевозки, выдерживая значительные температурные колебания. В-третьих, чай является достаточно дорогостоящим и компактным товаром, который легко складируется и транспортируется [6].

Именно этот товар и стал в XIX в. основным предметом торговли между Россией и Китаем. В силу этого основной маршрут, по которому караванами перевозился чай, получил название «Великий чайный путь» [5;9]. Великий чайный путь проходил по территории трех современных государств: Китая, Монголии и России. Поставка чая в Россию по ВЧП осуществлялась водным и сухопутным транспортом [2; 3].

К началу XIX в. сложился основной маршрут: Ханькоу — Тяньцзинь - Кяхта и далее по Сибирскому тракту. Основными пунктами приграничной торговли были Кяхта и Маймачен, через которые проходил самый короткий путь на Пекин из России через Ургу. С развитием коммуникаций, изменением внешнеполитических условий, включая большую открытость Китая для зарубежных стран, стали появляться другие маршруты Великого чайного пути, альтернативные Кяхтинскому: Амурский, Бийский, Туркестанский и морской. Вместе с тем малоизученными остаются вопросы их генезиса и экономической эффективности. В работе проведено исследование особенностей маршрутов, включая их недостатки и преимущества (табл. 1).

Амурский путь появился после подписания в 1858 г. Айгунского договора, в соответствии с которым российские суда получили возможность плавать по Амуру и его притокам. Чай поставлялся водным путем из Шанхая до Николаевска-на-Амуре, расположенного в устье Амура, а затем по реке до Сретенска. Дальнейшее движение по Сибири осуществлялось гужевым транспортом. Сухопутная транспортировка груза по территории России являлась основным пре- 
3. Б.-Д. Дондоков, А. Б. Базаров. Ретроспективный анализ экономической эффективности маршрутов монгольского коридора

имуществом данного маршрута, обеспечивавшим более высокие по сравнению с Кяхтинским маршрутом гарантии безопасной и своевременной поставки груза.

Из недостатков Амурского пути следует отметить нестабильность транспортировки грузов, что связано с малыми сроками навигации из-за замерзания Амура на 8 месяцев. В силу этого низкая скорость передвижения чая негативно влияла на оборачиваемость капитала. Кроме того, на конкурентоспособность маршрута отрицательно влиял недостаток пароходов надлежащей осадки, а также плохая дорога от Сретенска до Читы.

Таблица 1

Маршруты Великого чайного пути, альтернативные Кяхтинскому

\begin{tabular}{|c|c|c|c|c|}
\hline $\begin{array}{l}\text { № } \\
\Pi / \Pi\end{array}$ & $\begin{array}{c}\text { Наименование } \\
\text { маршрута }\end{array}$ & Основные этапы & Преимущества & Недостатки \\
\hline 1 & Амурский путь & $\begin{array}{c}\text { Ханькоу - } \\
\text { Шанхай - Ни- } \\
\text { колаевск-на- } \\
\text { Амуре - По- } \\
\text { кровка - Сре- } \\
\text { тенск - Верх- } \\
\text { неудинск - } \\
\text { Москва }\end{array}$ & $\begin{array}{c}\text { быстрая и дешевая } \\
\text { доставка чая сибир- } \\
\text { ским потребителям; } \\
\text { сухопутная часть } \\
\text { маршрута проходит } \\
\text { по территории Рос- } \\
\text { сии }\end{array}$ & $\begin{array}{c}\text { кратковременность } \\
\text { навигации по Амуру; } \\
\text { неудобная гористая } \\
\text { дорога от Сретенска } \\
\text { до Читы; } \\
\text { недостаточность } \\
\text { транспортных } \\
\text { средств }\end{array}$ \\
\hline 2 & Бийский путь & $\begin{array}{c}\text { Калган - Хух- } \\
\text { Хото - Улясу- } \\
\text { тай - Кош- } \\
\text { Агач - Бийск }\end{array}$ & $\begin{array}{c}\text { кратчайший путь до } \\
\text { Западной Сибири }\end{array}$ & $\begin{array}{c}\text { вьючная транспорти- } \\
\text { ровка чая по реке Чу } \\
\text { и через Саянский } \\
\text { хребет } \\
\end{array}$ \\
\hline 3 & $\begin{array}{c}\text { Туркестанский } \\
\text { путь }\end{array}$ & $\begin{array}{c}\text { Ханькоу - } \\
\text { Ханчжун - } \\
\text { Хами - Зайсан }\end{array}$ & $\begin{array}{c}\text { возможность бар- } \\
\text { терной торговли }\end{array}$ & $\begin{array}{c}\text { нестабильная поли- } \\
\text { тическая ситуация на } \\
\text { западе Цинской им- } \\
\text { перии } \\
\end{array}$ \\
\hline 4 & Морской путь & $\begin{array}{c}\text { Ханькоу - } \\
\text { Шанхай - } \\
\text { Кейптаун - } \\
\text { Санкт- } \\
\text { Петербург } \\
\text { (после } 1869 \text { г. } \\
\text { Порт-Саид - } \\
\text { Одесса) }\end{array}$ & $\begin{array}{c}\text { высокая скорость } \\
\text { транспортировки; } \\
\text { быстрый оборот } \\
\text { капитала }\end{array}$ & $\begin{array}{c}\text { высокие ставки ввоз- } \\
\text { ных пошлин }\end{array}$ \\
\hline
\end{tabular}

Рассчитано авторами на основе: [1]

В 1880-е гг. начал действовать Бийский путь, являвшийся кратчайшим маршрутом до рынков Западной Сибири, обеспечивающим возможность перевозки чая по Енисею и Иртышу. Главной проблемой данного пути являлась необустроенная инфраструктура перевозок, включая недостаток складских помещений, отсутствие надежных транспортных коммуникаций.

В 1870-1890 гг. была развернута торговля в русском Туркестане и Илийском крае, которые были соединены с Китаем двумя главными путями: первый - из Семиреченской области на Кульджу, Баркуль и т. д., а второй более южный - из Кашгара, Аксу, Хами на Ханькоу и Пекин. Чайная торговля в данных областях 


\section{ВЕСТНИК БУРЯТСКОГО ГОСУДАРСТВЕННОГО УНИВЕРСИТЕТА}

ЭКОНОМИКА И МЕНЕДЖМЕНТ

имела свои особенности, связанные с возможностью бартера на баранов и шкуры животных. К недостаткам Туркестанского маршрута следует отнести попутный характер чайной торговли, низкую скорость обращения капитала, высокий уровень политической нестабильности на территории, прилегающей к маршруту.

Тем не менее до 1870-х гг. Великий чайный путь оставался основным маршрутом поступления китайского чая в Россию, а Кяхта долгое время была практически единственным пунктом, через который осуществлялось экономическое и дипломатическое взаимодействие двух стран [7].

Морским маршрутом провозился только кантонский чай, так как другие порты были закрыты для европейцев, при этом в Кантон удобно завозить чай из внутренних областей Китая водными путями [10]. Главным и единственным маршрутом до 1861-1862 гг. являлся маршрут Кантон - Одесса, и этот маршрут был количественно ограничен. С 1861 г. Китай открыл все морские границы для международной торговли чаем. Все страны ввоза, включая Россию, значительно увеличили импорт чая благодаря низкой себестоимости перевозок. Пошлина с чаев морского транспорта постепенно увеличивалась, но вместе с тем все уменьшались накладные расходы.

С открытием Суэцкого канала в 1869 г. срок перевозки морским транспортом сократился почти вдвое: с 50-60 дней из Ханькоу в Одессу до 35-40 дней, что подтвердило неоспоримое преимущество морского транспорта перед сухопутным. Морской транспорт для чайных торговцев стал еще более быстрым, дешевым и безопасным.

В работе проведен сравнительный анализ затрат на доставку чая в центральную часть России (табл. 2).

Таблица 2

Калькуляция затрат на доставку чая в г. Москва, p./100 фунтов

\begin{tabular}{|c|c|c|c|c|c|c|}
\hline № & Статья затрат & $\begin{array}{c}\text { Кяхтинский } \\
\text { маршрут } \\
1861 \text { г. }\end{array}$ & $\begin{array}{c}\text { Морской } \\
\text { маршрут } \\
1861 \text { г. }\end{array}$ & $\begin{array}{c}\text { Кяхтинский } \\
\text { маршрут } \\
\text { кон. } \\
1880-\text { г гг. }\end{array}$ & $\begin{array}{c}\text { Амурский } \\
\text { маршрут } \\
1885 \text { г. }\end{array}$ & $\begin{array}{c}\text { Морской } \\
1890 \text { г. }\end{array}$ \\
\hline 1 & $\begin{array}{c}\text { Расходы на } \\
\text { закуп чая }\end{array}$ & 58,8 & 36,86 & 38,0 & 36,0 & 21,9 \\
\hline 2 & $\begin{array}{c}\text { Транспортные } \\
\text { расходы }\end{array}$ & 54,24 & 5,35 & 44,35 & 44,55 & 5,14 \\
\hline 3 & $\begin{array}{c}\text { Прочие расхо- } \\
\text { ды }\end{array}$ & 3,75 & 9,5 & 26,8 & 11,87 & 0,95 \\
\hline 4 & Пошлина & 15,0 & 30,0 & 52,5 & 28,19 & 78,76 \\
\hline 5 & Суммарные & 131,79 & 81,71 & 161,65 & 125,23 & 106,76 \\
\hline
\end{tabular}

Рассчитано авторами на основе: [1].

Сравнение суммарных затрат на доставку чая в Москву позволяет сделать вывод о низкой конкурентоспособности Кяхтинского маршрута к началу 1860-х гг. Ключевым фактором являлись высокие транспортные издержки. Несмотря на относительно низкую пошлину, расходы по Кяхтинскому маршруту значительно превышали затраты по морскому пути. 
3. Б.-Д. Дондоков, А. Б. Базаров. Ретроспективный анализ экономической эффективности маршрутов монгольского коридора

Открытие Суэцкого канала привело к изменению морского маршрута, значительно сократив его протяженность. Вместе с тем транспортные расходы в целом сократились незначительно — c 5,35 р. за 100 фунтов чая в 1861 г. до 5,14 р. в 1890 г.

Следует отметить, что Кяхтинский маршрут стал уступать по суммарным затратам Амурскому пути: в основном за счет более высокой пошлины, а также прочих расходов. Таким образом, сухопутный маршрут к концу XIX в. стал неконкурентоспособным по сравнению с водными или комплексными (вода + суша) маршрутами. Появление водных маршрутов с 1860 г. по окончании 2-й опиумной войны было обусловлено вынужденным «открытием» Китая для внешней торговли.

В целом можно сделать следующие выводы:

1. Основной причиной потери конкурентоспособности Кяхтинского маршрута стала потеря фактической монополии на перевозку чая из Китая в центральную часть России.

2. Изменение условий внешнеэкономического взаимодействия между Китаем и другими странами мира, в т. ч. Россией, привело к доступу зарубежных предпринимателей в ранее закрытые внутренние регионы страны. Следствием этого стало бурное развитие водных транспортных сообщений по основным рекам Китая, а также становление морских маршрутов по перевозке грузов, включая чай.

3. Открытие Суэцкого канала в 1867 г. лишь усилило конкурентные позиции морского маршрута по сравнению с сухопутными, включая Кяхтинский маршрут.

4. Протекционистская политика правительства России, заключавшаяся в повышении пошлин на перевозку чая морским путем до предельного уровня (73,8\% от суммарных издержек), в конечном счете не смогла обеспечить конкурентоспособность Кяхтинского маршрута ВЧП. Вследствие этого на исследованном историческом этапе он исчерпал свои возможности.

5. Из опыта Великого чайного пути применительно к современным условиям создаваемого экономического коридора Китай - Монголия - Россия вытекают следующий вывод: необходимо развивать не только торговлю и транспортную инфраструктуру, но и другие виды взаимодействия, включая совместные проекты по энергетическому кольцу, туризму, гуманитарные, научные и образовательные проекты. Урок Кяхты — это урок глобализации.

Работа выполнена при поддержке комплексной программы фундаментальных научных исследований СО РАН № II.I

\section{Литература}

1. Субботин А. П. Чай и чайная торговля в России и других государствах. СПб. : Тип. Северного Телеграфного Агентства, 1892.722 с.

2. Безруков Л. А. Транссиб и Шелковый путь в контексте восточного вектора России // Многовекторность в развитии регионов России / отв. ред. В. Н. Стрелецкий. М., 2017. С. 253-262.

3. Доржиева Т. С. Чайный путь на территории Бурятии: история и топонимия // Вестник Бурятского государственного университета. 2009. № 10. С. 3-8. 
4. Епифанова Г. В. Великий чайный путь: история и современность // Цивилизация - Общество - Человек. 2016. № 1(2-3). С. 36-42.

5. Косс Р. А., Плотникова М. М. Великий чайный путь и формирование локальной идентичности на примере городов Иркутска и Ханькоу // Вестник Пермского университета. Сер. История. 2015. № 3 (30). С. 128-134.

6. Кяхта - Маймачен. Прообразы свободных экономических зон в Российской империи: история, современность, перспективы [коллективная монография] / отв. ред. Л. Б. Жабаева. Улан-Удэ: Изд-во БГСХА, 2014. 201 с.

7. Мишакова О. Э. Кяхта: от караванной торговли до порто-франко. Из истории торговых отношений России и Китая в XVIII - первой половине XIX вв. // Вестник Бурятского государственного университета. 2011. № 7. С. 46-50.

8. Соколов И. А. Чай и чайная торговля в России: 1790-1919 гг. М.: Спутник+, 2012. $499 \mathrm{c}$.

9. Тагаров Ж. 3. Великий шелковый путь и трансевразийская чайная торговля через Кяхту // Иркутский историко-экономический ежегодник: сб. ст. Иркутск, 2016. С. 196203.

10. Цзайци Лю. Чайная торговля между Китаем и Россией // Теория и практика общественного развития. 2009. № 2. С. 63-75.

\section{LOOK BACK ANALYSIS OF THE ECONOMIC EFFICIENCY \\ OF THE MONGOLIAN CORRIDOR ROUTES}

Zorikto B.-D. Dondokov

Dr. Sci. (Econ.), Prof., Chief Researcher,

Department of Regional Economic Research BSC SB RAS

8 Sakhyanovoy St., Ulan-Ude 670000, Russia

E-mail: orei.bnc@mail.ru

Aleksandr B. Bazarov

Student,

Buryat State University

24a Smolina St., Ulan-Ude 670000, Russia

E-mail: sasha.bazarov.97@bk.ru

The article presents a look back analysis of the economic efficiency of the Mongolian corridor routes. We have compiled a list of the most important conditions and cargo properties for international trade between China and Russia. The reasons for the steady demand for tea as a main subject of trade between the states are determined. We analyze the major Kyakhta Tea Road and alternative Amur, Biisk, Turkestan and sea tea roads, the main points of the route, their advantages and disadvantages. The results of costing on tea routes are presented, and the reasons for declining the competitiveness of Kyakhta route are identified. Based on the analytical data, we draw up conclusions on competitive tea routes and given the recommendations for the conditions of China - Mongolia - Russia corridor.

Keywords: haulage of goods; tea routes; Mongolian corridor; tea delivery costs. 